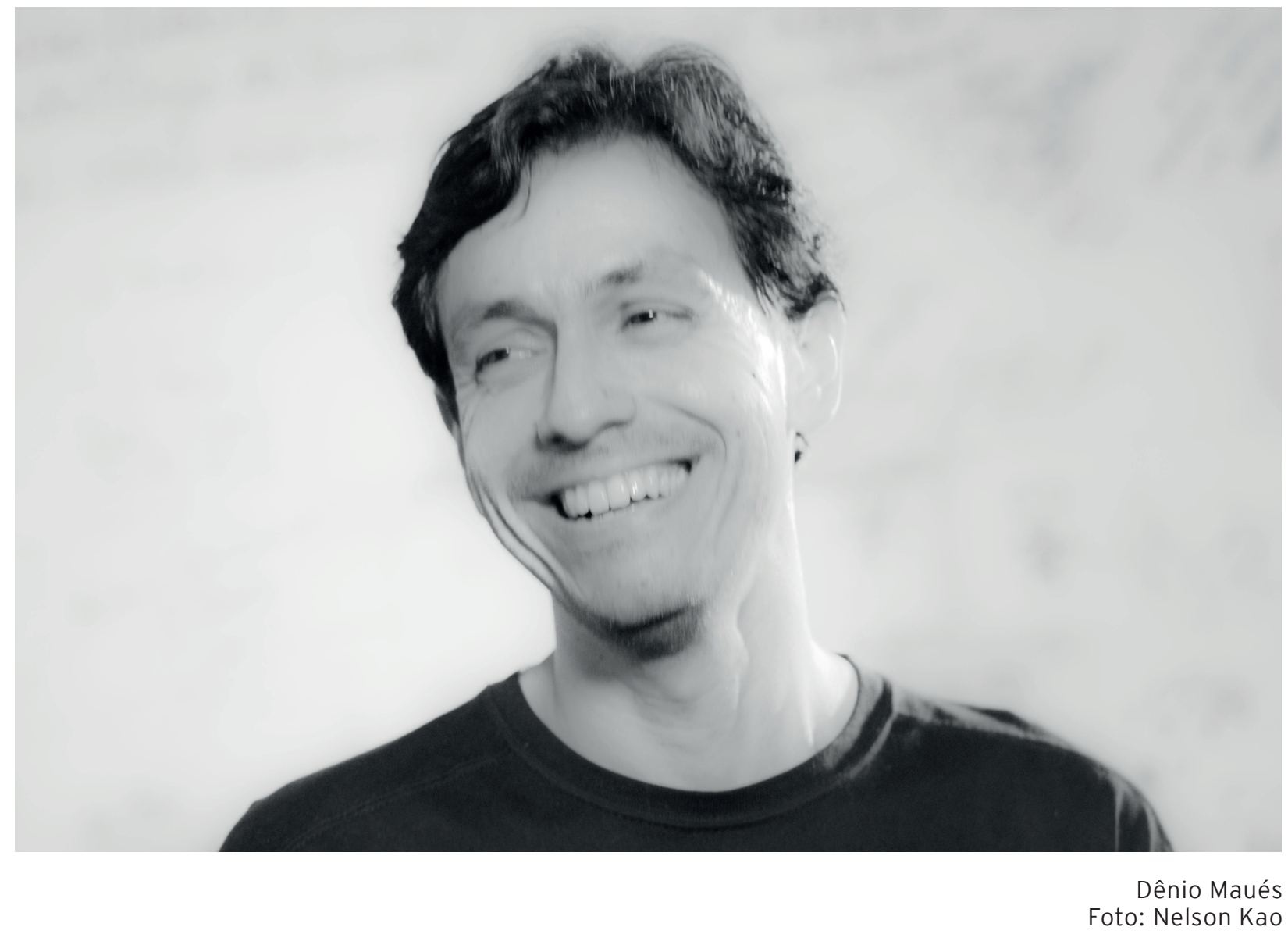

\title{
ENTREVISTA >> DÊNIO MAUÉS
}

\section{Entrevista concedida a Orlando Maneschy e Keyla Sobral em julho de 2017}

Denio Maués (1968) é autor teatral e jornalista. No teatro, sua peça "Escandinavos" foi apresentada em São Paulo, em 2016 (direção de Nicole Aun, com Andrea Tedesco); colaborou na dramaturgia do espetáculo "Ingratidão" (2013), direção de Cacá Carvalho, mostrada no circuito Sesc/SP; e lançou livro de peças em 2014, em projeto do Centro de Dramaturgia Contemporânea (CDC). Na área audiovisual, colaborou no roteiro do longa-metragem "Para ter onde ir", de Jorane Castro (2016); foi corroteirista e codiretor do documentário "Vila Madalena - Uma história e seus atores" (2006), exibido pela TV Cultura; e dividiu com Jorane Castro e Toni Soares a realização do videoarte "Cenesthesia" (Belém, 1988). Na literatura, tem cinco livros infanto-juvenis. No jornalismo, coordenou o setor de Relacionamento com a Imprensa da Unesp (Universidade Estadual Paulista), de 2003 a 2016, e adora fazer entrevistas. Em Portugal, participou, com o CDC, da residência artística "Capitanias dramatúrgicas", em Coimbra, em 2012. Morou no Japão entre 1996 e 1997, como bolsista na Chiba Television Broadcasting Corporation, onde realizou o documentário "Blondies in kimono". Mora em São Paulo.

1. Dênio, você fez Comunicação Social, é um dos autores de um marco da videoarte paraense, Cenestesia (1988). Como você vê, quase vinte anos após sua realização, essa experiência estética que virou cult? Fale sobre essa experiência do vídeo...

Dênio Maués "Cenesthesia" foi lançado em 1988, portanto completará 30 anos em 2018. É com muita alegria que eu vejo a recepção desse trabalho ao longo do tempo. Penso que "Cenesthesia" é daquelas 
obras que trazem o furor da juventude, dos 20 anos, com todo seu radicalismo e toda sua beleza. Quando Jô (Jorane Castro), Toni (Soares) e eu decidimos fazer o vídeo, tudo fluiu naturalmente. Toni propôs o argumento e nós três fizemos o roteiro, dirigimos e pensamos a edição. As ideias se complementavam e a vontade de contar aquela história daquela maneira foi algo que nos uniu esteticamente.

"Cenesthesia" surgiu a partir de um curso de roteiro que fizemos (eu, Jô e Toni) com Januário Guedes e Diógenes Leal, dentro do curso de Comunicação Social, na UFPA. As equipes poderiam gravar um vídeo, em VHS, como trabalho final. E nós levamos a missão à sério. Não queríamos perder tempo nem desperdiçar a oportunidade. Tínhamos a possibilidade de fazer um trabalho audiovisual e queríamos trabalhar as referências estéticas que gostávamos e absorvíamos. Algumas referências culturais eram comuns aos três, principalmente a partir do cinema, como "Estranhos no paraíso" (Stranger than Paradise), de Jim Jarmusch.

Tanto a Januário quanto a Diógenes, só podemos agradecer pela liberdade que nos deram. Diógenes fez a câmera e embarcou no que propusemos. O roteiro não era nem um pouco convencional, sabíamos disso e era exatamente o que queríamos. Cada cena tem sua ambiência e revela um aspecto da relação dos dois personagens. Queríamos mostrar a crise pela qual eles passavam trabalhando com a forma, então fotografia e edição deveriam traduzir a situação daqueles dois. Não criamos diálogos verbais, a informação das sensações se dá pelo gestual. Não há rostos em cena, apenas recortes (quando há). A partir de movimentos simples, exploramos o que poderíamos fazer com a imagem para tentar traduzir as dúvidas, angústias, conflitos e expectativas dos personagens: uma câmera subjetiva, uma sequência desfocada, entre outros.

"Cenethesia" se completou na edição e também só podemos agradecer ao Tim Penner, que fez um trabalho muito sensível, ouvindo o que queríamos, experimentando junto, propondo soluções. Um exemplo: passar para preto e branco (a captação foi em cor), fazer o título surgir letra por letra (acompanhando as onze notas da trilha composta pelo Toni), os letreiros finais que surgem e desaparecem. Assim como na direção, queríamos efeitos simples na edição, mas que traduzissem o estado de espírito da obra. Sem grandes elaborações teóricas. Claro, estudávamos teoria (Jô e eu no curso de Comunicação), mas em "Cenesthesia" o principal impulsionador foi de outra ordem.

Porém, um detalhe: apesar de ser um trabalho considerado experimental (e nada contra a palavra), para nós, "Cenesthesia" sempre foi uma ficção, no máximo uma ficção experimental na forma, mas com uma narrativa muito clara: um casal em crise afetiva/amorosa.

Toni criou também a trilha sonora original, que adoramos. Tem seu estranhamento, é eletrônica, é pesada em alguns momentos, mas doce em outros. Exatamente como vejo "Cenesthesia".

Um estímulo grande que recebemos foi do Wagner Fernandes, de quem Jô e eu fomos alunos e com quem dialogávamos sobre as novas estéticas audiovisuais. Após o lançamento na Mostra Vídeo Pará, no cine Líbero Luxardo, em 1988 (junto com mais cinco vídeos), Wagner fez uma resenha sobre a Mostra, publicada no Diário do Pará - salvo engano, na coluna da Risoleta Miranda. O que ele escreveu sobre "Cenesthesia" foi ao encontro do que pensávamos e gosto de pensar que ele gostou desse trabalho.

"Cenesthesia" não tem uma trajetória convencional e considero isso uma proximidade com todas as etapas do trabalho. Após algumas exibições públicas entre o final dos anos 80 e início dos 90, ele foi mostrado apenas para amigos próximos. Isso mudou a partir de 2009, quando Orlando Maneschy, então curador do Salão Arte Pará, o selecionou como trabalho convidado. Além da visibilidade em um grande salão, e na nossa cidade, "Cenesthesia" começou a ganhar uma discussão e um pensamento, dentro do contexto da videoarte paraense, encabeçada pelo Orlando e também com o Danilo Baraúna. Em 2016, eles fizeram a curadoria de uma mostra de videoarte da Amazônia para o CCA (Centre for Contemporary Arts) de Glasgow e "Cenesthesia" estava lá. Em 2017, Jô o inscreveu na 16ª Mostra do Filme Livre, que acontece anualmente no Rio de Janeiro e em Belo Horizonte e fomos selecionados, com outros poucos trabalhos audiovisuais de todo o Brasil. 


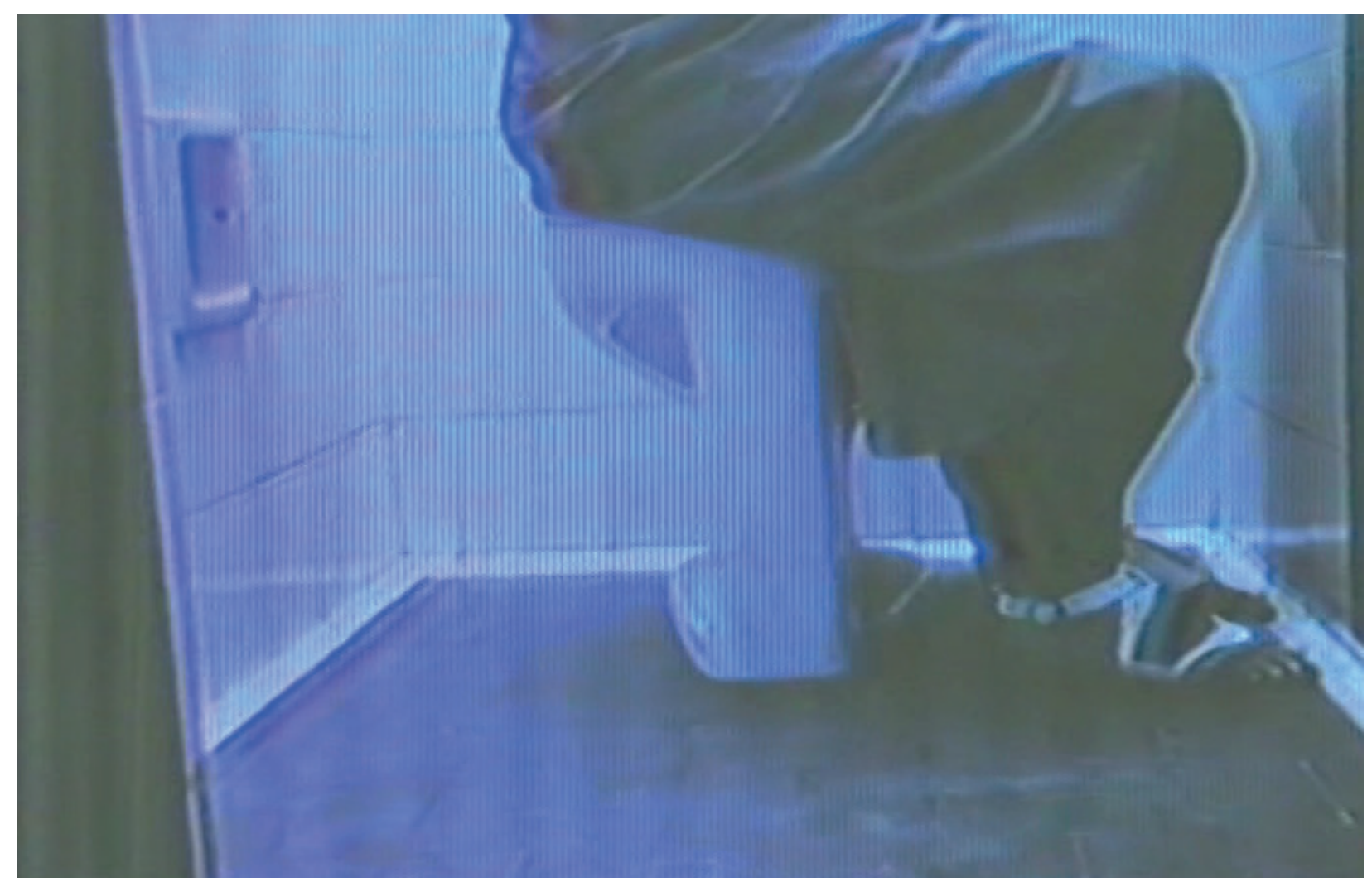

Cenesthesia

videoarte de Jorane Castro, Dênio Maués e Toni Soares

1988

Quando fizemos "Cenesthesia", não nos preocupamos, obviamente, se ele duraria 30 anos ou se tornaria referência na videoarte paraense. Resistiu ao tempo e ao sistema original em que foi feito (VHS). É uma alegria. Gosto muito de ter feito "Cenesthesia", gosto de tê-lo feito com os parceiros que fiz. "Cenesthesia" só existe porque tivemos a sorte desses encontros. Três décadas depois, espero que mais pessoas o assistam e adoraria saber como a percepção sobre esse trabalho se dá hoje.

De lá para cá, fiz alguns trabalhos audiovisuais, embora tenha me dedicado mais à escrita, território que compreendo melhor - tanto que, em alguns trabalhos, fiquei mais ocupado com o roteiro, com a pesquisa ou até com entrevistas (se for um documentário), o que se aproxima da minha formação em Jornalismo. Exatamente com roteiro fiz outro trabalho com a Jorane, colaborei na etapa final da escrita do longa-metragem "Para ter onde ir". Jô me enviou o último tratamento, mergulhei nas histórias sensíveis daquelas três heroínas e propus algumas coisas a partir do roteiro dela. Não pude acompanhar as filmagens, mas fiquei muito feliz por estar presente nesse projeto que retoma o longa-metragem no Pará, após décadas. E gostei muito do resultado final, das soluções encontradas e de como o tempo é trabalhado ali.

A imagem em movimento continua sendo uma possibilidade estética muito estimulante para mim, em especial a videoarte, pela fuga dos padrões convencionais da imagem e pelo que ela pode propor. E também pela intimidade. Nunca me imaginei dirigindo uma grande equipe num set de cinema, acho incrível e genial quem consegue administrar tantas questões (o mesmo vale para uma peça com grande elenco ou um musical). No campo da videoarte, tenho alguns trabalhos que pretendo retomar e finalizar, como uma série de pequenos registros que fiz no projeto "Água - Mídia Locativa", residência artística fluvial, coordenado pela Val Sampaio, entre os rios Amazonas e Tapajós. São trabalhos onde exploro a questão do tempo amazônico, com planos-sequência de determinadas situações. 


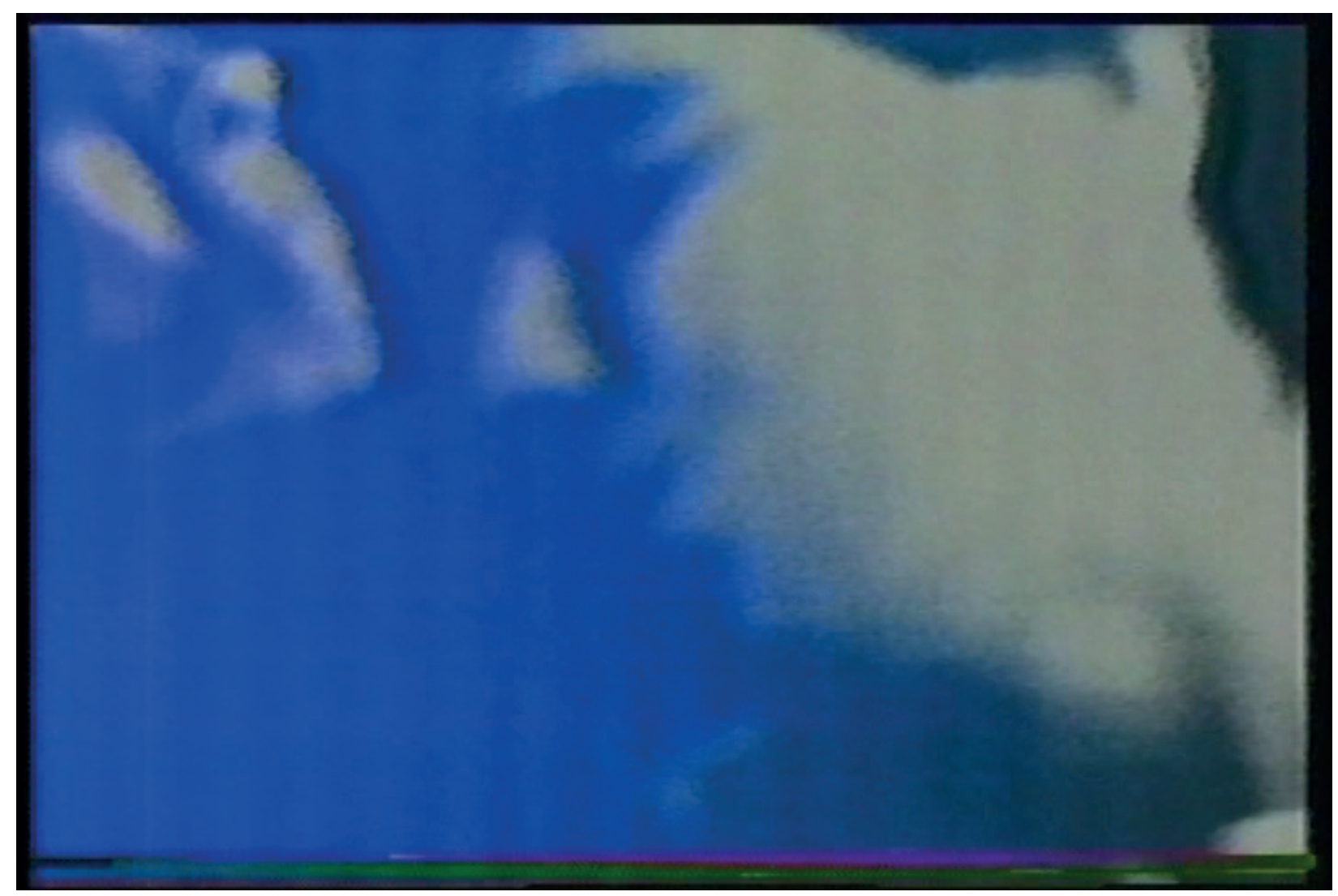

Cenesthesia

videoarte de Jorane Castro, Dênio Maués e Toni Soares

1988

2. Fostes como bolsista ao Japão e terminastes realizando também um trabalho em vídeo. Como se deu esse mergulho em uma cultura tão diferente? Já percebias a força da narrativa nesse momento em teu trabalho?

Dênio Maués Pois é, morar do outro lado do mundo é uma experiência daquelas únicas na vida. Morei no Japão por quase um ano. Lá, meu idioma era o inglês, por uma questão prática, mas busquei sempre uma integração grande com os japoneses e fiz amigos, numa era ainda sem Facebook, o que fez com os contatos acabassem se perdendo...

A ida para o Japão ocorreu quando eu trabalhava no Museu da Imagem e do Som, em Belém. Assim, por conta da bolsa, eu propus um trabalho que unisse imagem e aspectos culturais. Fiquei como bolsista por quase um ano em uma emissora de televisão, a Chiba Television, da cidade de Chiba, e eles atenderam o meu pedido: eu acompanhava o trabalho de produção das equipes que faziam programas sobre a cultura japonesa e acompanhava as gravações. Assim, pude ver ao vivo várias manifestações culturais, além de cerimônias budistas e xintoístas que raramente um estrangeiro está presente. Cidades pequenas com restaurantes em que o cardápio está apenas em kanji (o ideograma japonês), sem letras do alfabeto latino.

Tudo isso complementado com Tokyo e toda sua extrema urbanidade, modernidade, pós-modernidade: a cidade de Chiba fica a uma hora de trem de Tokyo, então, nos finais de semana, eu estava constantemente absorvendo a loucura daquela megalópole. $E$, durante a semana, voltava para o Japão das tradições. Fora isso, aprendi a conviver com pequenos terremotos cotidianos (felizmente nenhum de grande intensidade, mas suficientes para fazerem balançar as luzes do estúdio da TV ou os pratos e copos se baterem no armário de casa) e também tufões, porque a cidade de Chiba é banhada pela baía de Tokyo.

O vídeo que fiz lá foi um presente dos diretores da TV, ao final da bolsa. Eu poderia fazer um trabalho de até dez minutos e teria uma equipe à minha disposição para as gravações, mas apenas por um dia. Para 


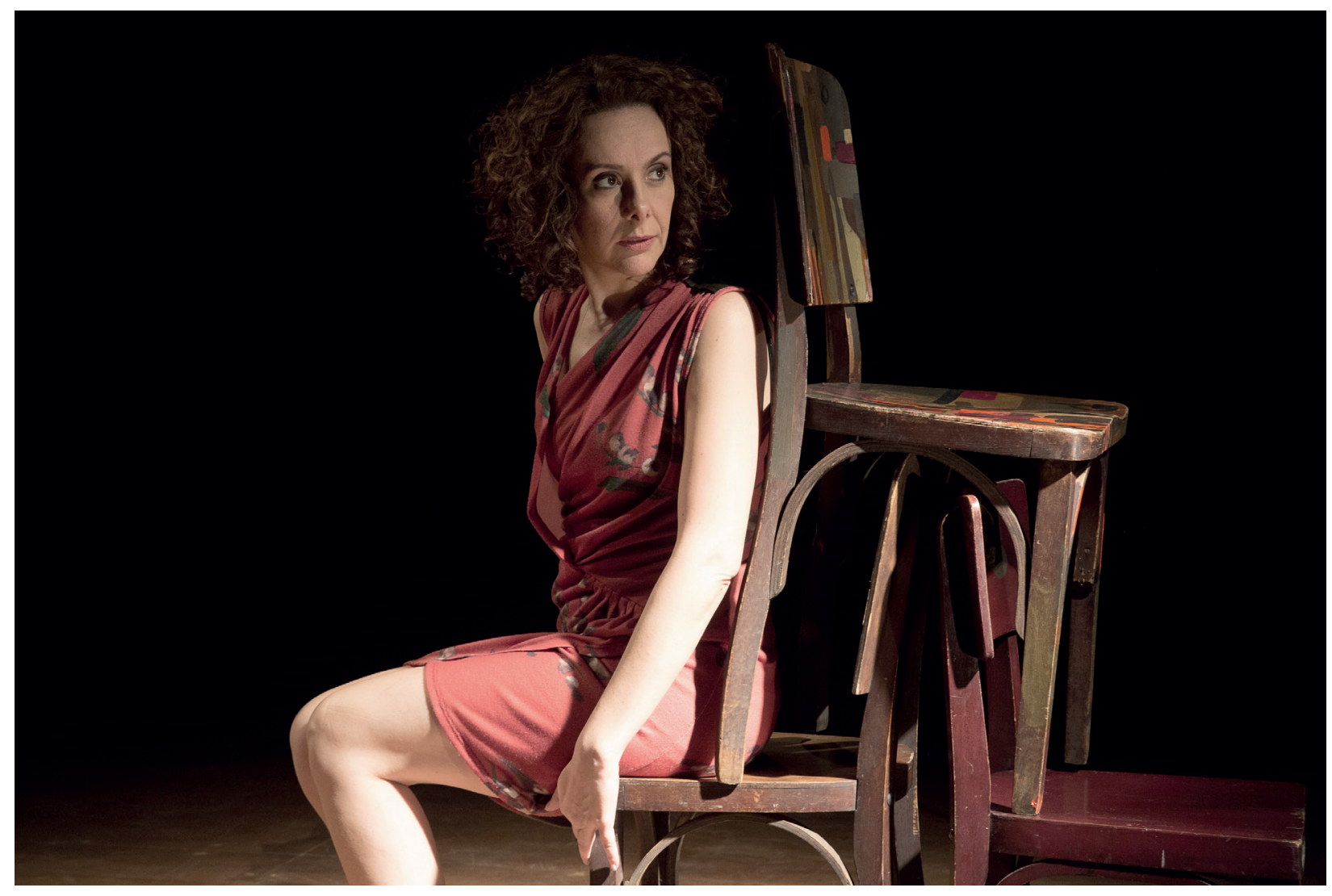

Peça "Escandinavos"

Foto: Marcelo Patu

se planejarem, eles me pediram um breve roteiro e um story board. Como teria de ser algo simples, já que teria apenas um dia, optei por um mini-documentário baseado em entrevistas de rua com jovens japoneses que, questionando a cultura japonesa milenar, pintam seus cabelos de cores variadas, como no Ocidente. Entrevistei também outras pessoas que opinavam sobre isso, como jovens mais tradicionais, idosos e estrangeiros.

A partir de algumas perguntas, procurei mostrar o momento de afirmação desses jovens com essa pequena "transgressão pop" e como eles se imaginavam dentro de alguns anos, quando, mais velhos, tivessem de procurar emprego e entrar no sistema e assim, provavelmente, teriam de voltar ao cabelo preto tradicional que a sociedade nipônica aprova. Nesse trabalho, tive o apoio de uma intérprete para as entrevistas e, depois, uma bolsista brasileira descendente de japoneses me ajudou na legendagem em português, na edição. O vídeo chama-se "Blondies in kimono".

3. Efetivamente em que momento se deu o teatro como campo de experiência? Como ocorreu esse fluxo de linguagens?

Dênio Maués Para mim, a experiência teatral se dá, basicamente, pelo viés da dramaturgia, ou seja, da construção dramática por meio da palavra que cria (ou recria) situações, falas e personagens. $E$, a partir do texto, me permito investigações sobre formas de se contar uma história no espaço e no tempo; descobrir quem é esse personagem, como age e como sua fala surge - por meio de diálogos, monólogos, repetições e até silêncios e até o não-dito.

Gosto da análise de Jean-Pierre Sarrazac, teórico francês, para quem o drama representa, nos dias atuais, uma "forma híbrida da modernidade" e podemos, com a mais absoluta liberdade, trabalhar com 


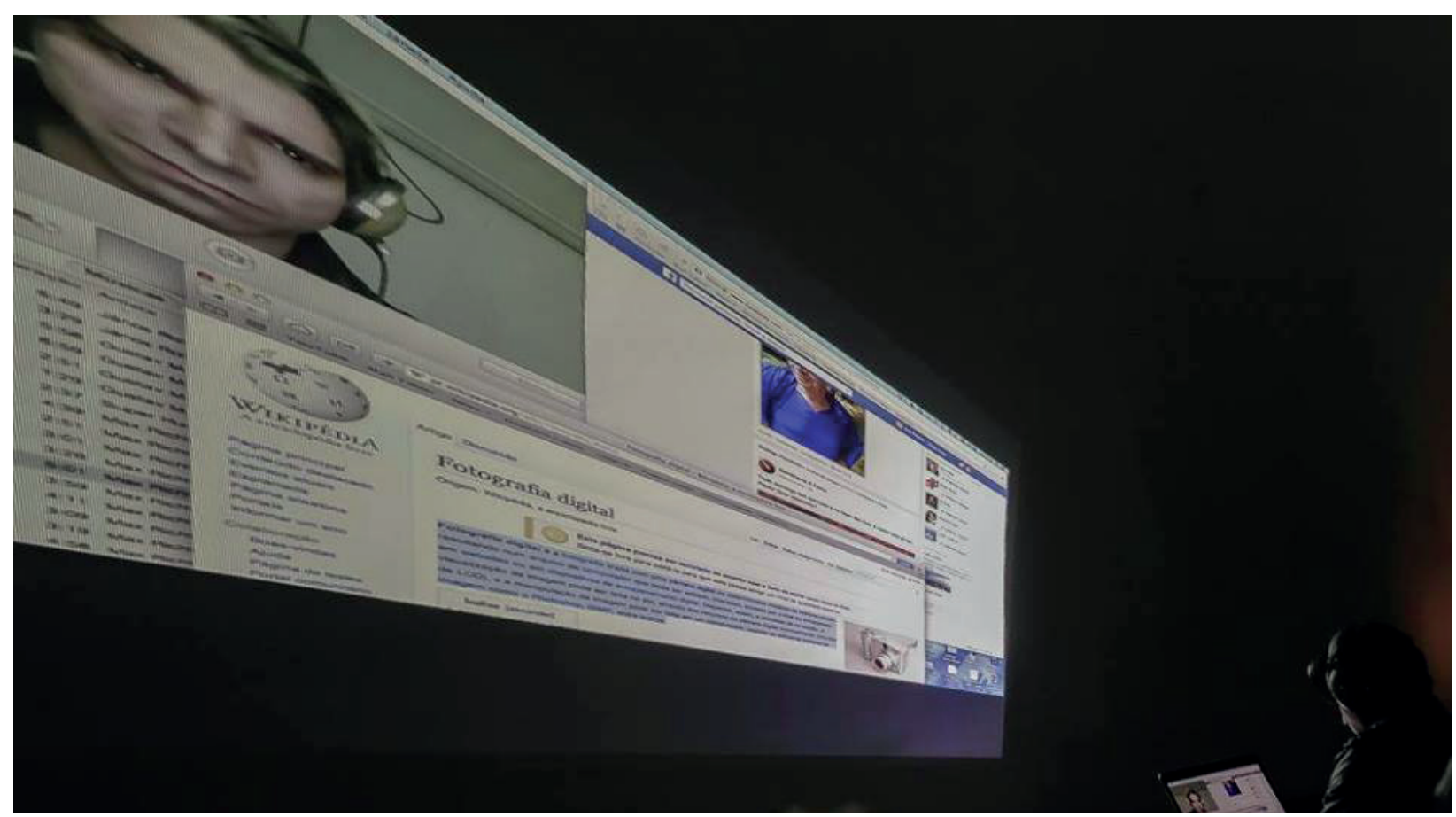

Peça "Espera"

Foto: Paulinho Faria

os gêneros teatrais, como o dramático e o épico, e buscar a melhor relação entre conteúdo e forma. Particularmente, venho buscando uma parceria com atores e diretores, que trazem seus olhares para o meu texto e, muitas vezes, podem investigar junto, já no campo da encenação. Um exemplo recente são os textos "Escandinavos" e "Espera", quase sem rubricas (definições de ação). "Escandinavos" foi encenada em 2016, com Andrea Tedesco no elenco e direção de Nicole Aun, com temporada na sala experimental do Teatro Augusta, em São Paulo. "Espera" teve uma leitura encenada em 2014, pelo diretor José Roberto Jardim. Em ambas, os diretores, que são talentosíssimos, fizeram um mergulho no texto e propuseram a encenação. Os resultados foram inesperados e fascinantes. Nicole eu conheci quando trabalhei com Cacá Carvalho, na dramaturgia da peça "Ingratidão", em 2013, e ela fazia assistência de direção para o Cacá.

Minha primeira experiência com a dramaturgia se deu em Belém, ainda nos anos 90, quando escrevi um monólogo de uma personagem feminina, em uma antiga máquina de escrever. Não fiz nenhuma cópia e essa peça se perdeu nas diversas mudanças - de casa, de cidade, de país. Já em São Paulo, resolvi retomar a dramaturgia em 2006, a partir de um grupo de escrita teatral coordenado pela dramaturga Paula Autran. Naquele mesmo ano, Paula propôs a criação do Centro de Dramaturgia Contemporânea, grupo do qual faço parte. Tive minha primeira peça encenada em 2009 ("Jardim inverso", coautoria com Drika Nery e Luis Eduardo de Sousa e direção de Paulo Faria), outras peças curtas se seguiram ("Bemvindos", "O mundo lá fora"), além de leituras dramáticas e participações nas Satyrianas (festival anual em São Paulo) até acontecer a temporada de "Escandinavos" - por coincidência, um monólogo feminino, como se fechasse um ciclo com aquela primeira peça perdida.

Nessa investigação dramatúrgica, gosto de construir a história com tempos e espaços diferentes e/ ou simultâneos, lançando mão de recursos diversos, como a narração - que pode ser mentirosa - e a memória do personagem, sem contar a liberdade que as convenções teatrais permitem, quando o palco 


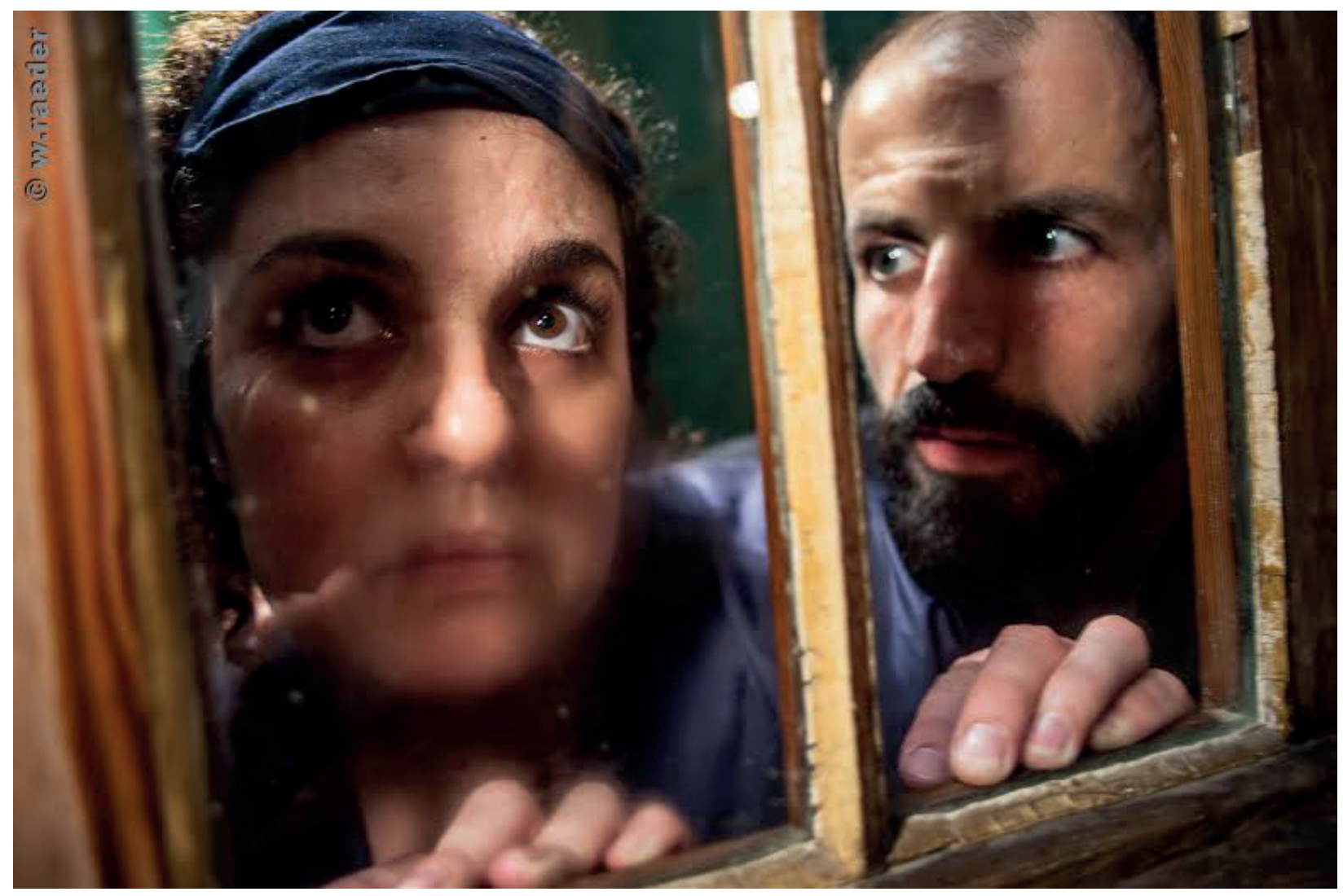

Peça "O mundo lá fora"

Foto: Wlad Raeder

pode ser um ou mais lugares e um objeto pode ser ressignificado. Comecei a explorar mais fortemente esses tempos e espaços em 2012, no texto "Transatlântico", escrito em uma residência artística em Coimbra, cuja trama se passa no Brasil e em Portugal, simultaneamente nos séculos 19 e 21, explorando essa característica tão brasileira de sermos avançados tecnologicamente e não deixarmos de ser, na alma e na essência, uma sociedade escravocrata. Na dramaturgia, gosto também de explorar as lacunas que uma narrativa pode conter (provocadas por lapsos de memória, contradições, distrações, fluxos de pensamento ou mesmo uma conversa bruscamente interrompida).

Em relação à montagem, como costumo convidar diretores, procuro não interferir na proposta cênica. Sempre busco me concentrar no tripé história-personagem-palavra, daí que indico pouquíssimos objetos de cena, variações de luz ou figurinos. Apesar da minha experiência com o audiovisual, também não costumo propor recursos multimídia na minha dramaturgia; caso a leitura do diretor vá nessa direção, acharei ótimo (como na performance que o diretor Nando Lima fez em Belém, em 2015/2016, no Espaço Reator, para um texto meu, "Em caso de emergência quebre o vidro", a partir de sua experiência com a videoarte; ou as projeções que Zé Roberto Jardim utilizou em "Espera"). Mas se o diretor quiser fazer uma encenação somente com atores e falas, essa base está no meu texto. Cada diretor traz seu olhar para o meu trabalho.

E o teatro vem me trazendo alguns presentes, como o trabalho com grandes artistas em São Paulo com é o caso de Cacá. E também convites inesperados, como a participação, em Belém, em 2015, no Seminário de Dramaturgia Amazônida, da Escola de Teatro e Dança da UFPA. Ter feito uma palestra sobre minha experiência teatral paulistana para uma platéia generosa composta por artistas paraenses que sempre vi e cena e admiro, gerou uma sensação muito prazerosa, mas carregada de responsabilidade. 
4. Tuas postagens no Instagram parecem reunir essas tuas duas potencias. Percebes isso? Como vês?

Dênio Maués Considero o Instagram uma rede social ótima para alguns trabalhos audiovisuais pelo formato, pela agilidade, pelas possibilidades de compartilhamento com outras mídias.

Quando posto, procuro fazer uma narrativa nas fotos ou vídeos, aproveitando a disposição dos três quadros disponíveis, brincando de fazer trípticos ou dípticos, às vezes mais explícitos e até numerados; às vezes, com uma associação mais livre.

Penso que o campo da imagem digital, fotografia ou vídeo, permite cada vez mais qualquer experimentação. $\mathrm{E}$, claro, podemos/devemos usar essas mídias como bem entendermos: eventualmente, pode-se quebrar alguma possível regra e fazer um registro de uma viagem, de encontro com amigos ou do seu animal de estimação, postar a capa de um livro incrível ou até mesmo um selfie. Acaba sendo uma pequena e particular galeria online, com as experiências de cada um, artísticas ou não, cotidianas ou não. Mas, acredito, afetivas na maior parte das vezes.

5. Na Peça Escandinavos fazes uma referência a Bergman, bem como à cantora islandesa Björk, o que revela ao público seus interesses e por onde caminhas. Quem mais povoa seu imaginário poético?

Dênio Maués Sim, "Escandinavos" faz uma referência a Ingmar Bergman e Liv Ullmann (mas não explícita, eles não são citados nominalmente, apenas como "o diretor sueco" e a "atriz norueguesa" que um dia foram casados e, depois de separados, voltaram a trabalhar juntos. Como são dois ícones muito fortes, 0 texto acabou girando em torno de outras referências escandinavas, como a Björk - que adoro - a cultura viking e o mito das Valquírias. De certa forma, vejo esse mergulho como uma pequena homenagem aos dois (Bergman e Liv Ullmann). Por outro lado, a personagem da história é extremamente brasileira e latina, e faz uma aproximação muito particular com os costumes escandinavos ao narrar ao público o momento pelo qual está passando: ela é uma atriz na tentativa de reaproximação com o homem do qual está separada - um ator -, e com o qual pretende fazer uma peça sobre o relacionamento já terminado.

O que povoa meu imaginário poético? A música, a cultura pop, a questão tecnológica (com seus benefícios e problemática), a escrita livre da poesia e alguns dramaturgos, como Beckett, o norueguês Jon Fosse ou a inglesa Sarah Kane, por suas escritas contemporâneas.

A música está sempre presente nos meus textos ("Em caso de emergência quebre o vidro" traz citações de canções dos Smiths; em "Transatlântico" ouve-se um fado; "Bandoneon", texto ainda em construção, gira em torno do tango). Ainda não usei um tecnobrega, mas está nos planos. A tecnologia surge forte em "Espera" e em "Transatlântico" (quando a ação está no século 21). A escrita poética aparece em "Escandinavos" e em "Espera", quando o texto busca seu ritmo ao quebrar linhas no meio de frases ou trabalhar com reticências para simbolizar pausas, breves ou longas.

E também quero tratar, a exemplo de "Transatlântco", de assuntos cotidianos que julgo importantes. Em "O mundo lá fora", por exemplo, o medo da violência e a paranoia urbana. Em "Bullying: que brincadeira é essa?", peça infanto-juvenil, trato desse tipo de violência escolar entre adolescentes. Mas, sempre que possível, com ironia, humor e sentimento.

6. Para quem quer escrever para teatro, qual exercício recomendas? A escrita literária e cinematográfica seria um dos começos para esse percurso?

Dênio Maués Como diz o teórico Eric Bentley, o dramaturgo deve escrever sempre, dedicar o máximo de horas para isso. A escrita (não só teatral) exige um tempo para ela, o que significa leituras e reescritas. E, para deixar claro, falo aqui de escrita autoral. Mas toda prática será benéfica, seja para um texto de autoria própria, seja para um texto produzido em processo colaborativo (na sala de ensaio, com os atores) - mas, neste caso, a dinâmica é completamente diferente e o texto é feito a partir do grupo. 
Sobre começos, penso que a dramaturgia, a literatura e o roteiro cinematográfico, embora tenham pontos de contato, são muito diferentes entre si. Mas podem ser um começo, claro. E, fatalmente, uma escrita vai influenciar a outra, o que pode ser saudável. Agora, no caso do cinema, penso que, depois da experiência dramatúrgica, chega-se com mais vigor ao roteiro. No meu caso, a dramaturgia foi importante para isso e, inclusive, para as experiências literárias, com personagens e histórias mais solidamente construídos.

Deve-se, sempre que possível, ler peças, brasileiras e estrangeiras, de todas as épocas, de Shakespeare a Brecht, de Plínio Marcos a Koltès, das tragédias gregas aos autores brasileiros contemporâneos. Aliás, o dramaturgo deve, sempre que possível, tentar publicar suas peças, para que a obra circule e ele também seja lido, aumentando suas chances de ser encenado. Tenho quatro peças publicadas, "Escandinavos", "Em caso de emergência quebre o vidro", "Espera" (as três em um mesmo livro, dentro de uma coleção do Centro de Dramaturgia Contemporânea com sete livros, um de cada autor do grupo) e "Bullying: que brincadeira é essa?". A leitura de teóricos contemporâneos que pensam a dramaturgia também é importante, como o francês JeanPierre Ryngaert, o brasileiro Luiz Fernando Ramos, além do Sarrazac e Bentley que já citei, entre outros.

E fundamental: ir ao teatro. Assistir peças e ver como se dá a encenação, pois a dramaturgia é uma escrita que tem como finalidade o palco. Essa prática é muito importante para quem escreve, para que se tenha noção de questões de produção - ainda que não necessariamente o autor vá cuidar disso -, e como se dá a transposição do texto para a cena: que formas o diretor vai encontrar para viabilizar a "concretização" do texto, seja por escolhas estéticas, seja por adequações orçamentárias. O dramaturgo deve ter em mente, antes de tudo, a liberdade do teatro, que pode abrir mão do realismo e conseguir, com uma direção criativa, resultados poéticos e potentes. E não deve se esquecer nunca do poder da dramaturgia, que permanece ao longo do tempo. Poucas coisas são mais intensas do que ver um texto de séculos atrás, no palco, dialogando com nosso tempo e fazendo sentido para o nosso cotidiano. Alguns autores conseguem isso.

\section{Sobre o entrevistador}

Orlando Maneschy é curador independente, artista e pesquisador. Doutor em Comunicação e Semiótica pela PUC-SP. É professor na Universidade Federal do Pará, atuando na graduação e pósgraduação. É líder do grupo de pesquisas Bordas Diluídas - UFPA/CNPq; coordena o programa de extensão Processos Artísticos e Curatoriais Contemporâneos. É curador da Coleção Amazoniana de Arte da UFPA. Membro da Associação Nacional de Pesquisadores em Artes - ANPAP, fazendo parte de sua diretoria (2013 - 2014) e de outros comitês. Dentro de suas ações há a criação e articulação do Mirante - Território Móvel, uma plataforma de ação ativa que viabiliza proposições de Arte. Vem desenvolvendo e participando de projetos de pesquisa, artísticos e curatoriais no país e exterior.

Keyla Sobral é artista visual, mestra em artes pela UFPa e doutoranda pelo Programa de Pós-graduação em Artes pelo Instituto de ciências da arte da Universidade Federal do Pará. Como artista, vem participando de mostras de arte, de residências artísticas no País e no exterior. Foi curadora assistente do Projeto Amazônia: Lugar da Experiência, bem como co-organizadora do livro Amazônia, Lugar da Experiência - Processos Artísticos da Região Norte (2013). É integrante do grupo de pesquisa Bordas Diluídas -CNPq e do grupo de pesquisa Laboratório Ambiento-Corporais em Atravessamentos e Experimentações: Imaginação, Amor, Arte e Política na Amazônia (Lab AMPE) - CNPq. 